\title{
When I feed medical patients
}

\section{By D. B. A. Silk, Department of Gastroenterology, Central Middlesex Hospital, London NW10 ${ }_{7} N S$}

It is nearly to years since Bristian et al. (1976) published their paper showing that up to $50 \%$ of hospitalized general medical patients had some evidence of nutritional deficiencies. Their findings had often been interpreted as implying that up to $50 \%$ of their patients were 'malnourished' and in need of nutritional support. Unfortunately it has become clear that it is difficult, even impossible, to agree on what actually represents clinically significant malnutrition (Sutton \& Karran, 1985). Even if there is agreement that a patient is malnourished, it may not be clear that outcome will be prejudiced and, therefore, whether nutritional support will be cost effective or of benefit to the patient. It is hardly surprising that agreement on these points has not been reached, since in the hospitalized patient, malnutrition often arises as a consequence of the underlying disease process which may not be amenable to correction. Research is still being undertaken to improve the definition of malnutrition. Two recent studies (Gassull et al. 1984; Pettigrew et al. 1984) continue to highlight the problems involved, namely the arbitrary setting of normal limits and the validity of the derived definitions.

If one accepts that we are still unable to define what constitutes 'clinically significant' malnutrition, then it seems logical to continue to divide patients into 'high'- and 'low-'risk groups either on the basis of individual nutritional indices or by using complex 'weighting' systems (Mullen et al. 1980; Jeejeebhoy et al. 1982). Although such studies enable one to predict with some certainty whether a patient is likely to be at risk of suffering increased morbidity or mortality, the question as to whether nutritional support affects morbidity or mortality in the 'high-risk' malnourished group remains largely unanswered. This is because most clinical trials of nutritional support have not been properly designed and have included normally-nourished as well as malnourished patients (see Silk, 1983; Koretz, 1984).

If clinical trials were to be designed sensibly, i.e. a 'high-risk' malnourished group identified, randomized to receive normal nutritional intake, or this plus nutritional support, then valuable information could be gained as to whether nutritional support can influence outcome, or outcome is influenced by the underlying disease process. By such means, the central question 'is malnutrition clinically significant?' could be answered. One such trial has been performed recently by Bastow et al. (1983) who showed that malnutrition in elderly female patients with fractured femurs was likely to be clinically significant. Patients who received supplementary nasogastric feeding had a significantly quicker rehabilitation and earlier discharge from hospital than did the control malnourished patients. 
Table I. Clinical sequelae of severe malnutrition (after Lee, 1979)

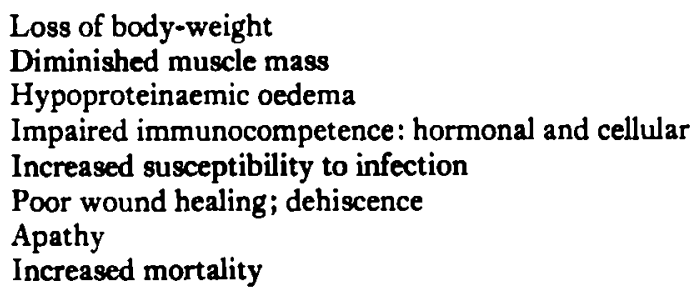

\section{When to institute nutritional support}

If it remains difficult to define 'clinically significant malnutrition', and there is little reliable information from controlled clinical trials, how can the problem of whether or not to institute nutritional support be best tackled? The following factors should influence decision making.

\section{Clinical sequelae of malnutrition}

There can be little doubt as a result of a number of epidemiological studies that clinical malnutrition, which can be equated with negative nitrogen balance (Lee, I979), has serious clinical sequelae (Table I) and knowledge of these should influence decisions about instituting nutritional support. Thus, nutritional deficiency leads to a significant increased susceptibility to infection (Scrimshaw $e t$ al. 1959, 1968; Shizgal et al. 1976; Spanier et al. 1976; Meakins et al. 1977; Dowd \& Heatley, 1984; Selivanor \& Shelden, 1984) and poor wound healing (Daly et al. 1972). It is possible to improve experimentally the 'strength' of intestinal anastomoses with nutritional support (Rolandelli $e t$ al. 1985 ).

\section{Factors contributing to malnutrition}

One of the commonest factors contributing to malnutrition is inadequate intake of nutrients before admission, due to the underlying disease process (e.g. mechanical dysphagia due to a carcinoma of the oesophagus). In two recent controlled trials our patients had received a grossly inadequate diet for 2 and 3 weeks before enteral nutrition was instituted (Jones et al. 1983; Keohane et al. $1983 b$ ). Metabolically, the changes that occur in such patients are synonymous with 'starvation'. A second major factor contributing to malnutrition is the 'injury' sustained (the term 'injury' includes trauma, surgery, sepsis and burns). In very important ways, the metabolic responses to starvation and injury differ (for reviews, see Woolfson, 1979; Silk, 1983).

(a) The starved patient. Here, the metabolic changes are geared to reduce losses of body constituents. Insulin levels fall, glucagon levels rise, the basal metabolic rate (BMR) falls, the hormonal milieu is such that up to $95 \%$ of energy production is finally derived from fat (Grande, 1968) and protein mass is spared with $\mathrm{N}$ losses falling from 8-10 to $2-4 \mathrm{~g} / 24 \mathrm{~h}$ (Woolfson, 1979). As long as there is no coexisting 'injury' the totally-fasted patient may survive as long as $40-60 \mathrm{~d}$. 
(b) The 'injured' patient. The short (6-8 h) 'ebb' phase of injury is characterized by an increase in catecholamine secretion (Woolfson, 1979). The purpose is to allow escape to safety and to maintain blood volume. In clinical terms the 'ebb' phase constitutes the immediate post-operative period following surgery, when attention should be paid to achieving haemodynamic stability. The 'flow' phase is the most important period as far as nutritional support is concerned as it is the time when the major metabolic changes geared to meeting increased energy demands occur. The most important aspect of the 'flow' phase is that basal energy requirements increase and the BMR rises. It is thought that this increased demand in energy is met by the hormonal changes which are characterized by increased production of circulating glucagon (Cope et al. 1943), growth hormone (Ross et al. 1966), cortisol (Cope et al. 1943) and insulin. In the case of insulin, however, 'resistance' to its action occurs (Allison et al. 1968). These changes result in mobilization of adipose triglyceride and breakdown of muscle protein to provide energy from lipolysis, branched-chain amino acid (BCAA) oxidation in muscle and gluconeogenesis. In contrast to energy production in starvation, a maximum of only $80 \%$ of energy demands in the injured patient can be derived from fat (Kinney et al. 1970); the remainder is met from protein breakdown. It follows that weight loss is marked in response to this increased energy demand and is often as high as $1.5 \mathrm{~kg} / 24 \mathrm{~h}$. Recent work shows that this is not only caused by fat and protein breakdown, but also by diminished protein synthesis (O'Keefe et al. 1974). Moreover the increases in protein breakdown, as well as decreased synthesis, explains why $\mathrm{N}$ losses are so high in severe injury.

In the third phase of the metabolic response to injury, the 'anabolic' phase, the hormonal response is reversed, BMR falls and patients can attain positive $\mathbf{N}$ balance.

(c) The mixed picture. The metabolic changes in starvation are geared towards conserving energy output, whereas in response to injury the metabolic response is geared towards coping with the increased energy demands and it follows that nutritional requirements will be markedly different.

In practice patients often do not fall simply into one or the other category. Frequently they may suffer injury after a period of undernutrition, e.g. oesophagogastrectomy after a period of starvation due to mechanical dysphagia; chest infection following undernutrition as a consequence of a stroke. While the magnitude of the increased energy requirements in response to injury is governed largely by the size of the injury (Moore, 1959), the requirements are reduced at any given injury size by previous starvation (Abbott \& Albertsen, 1963).

\section{Natural history of the underlying disease process}

In the author's opinion one of the most important aids to deciding whether to institute nutritional support in medical or surgical patients is a knowledge of the natural history of the underlying disease process. Too often nutritional support for the patient is requested too late (e.g. the patient who is considered to have a reversible neurologic defect, but who has been starved for $3-4$ weeks) and too often 


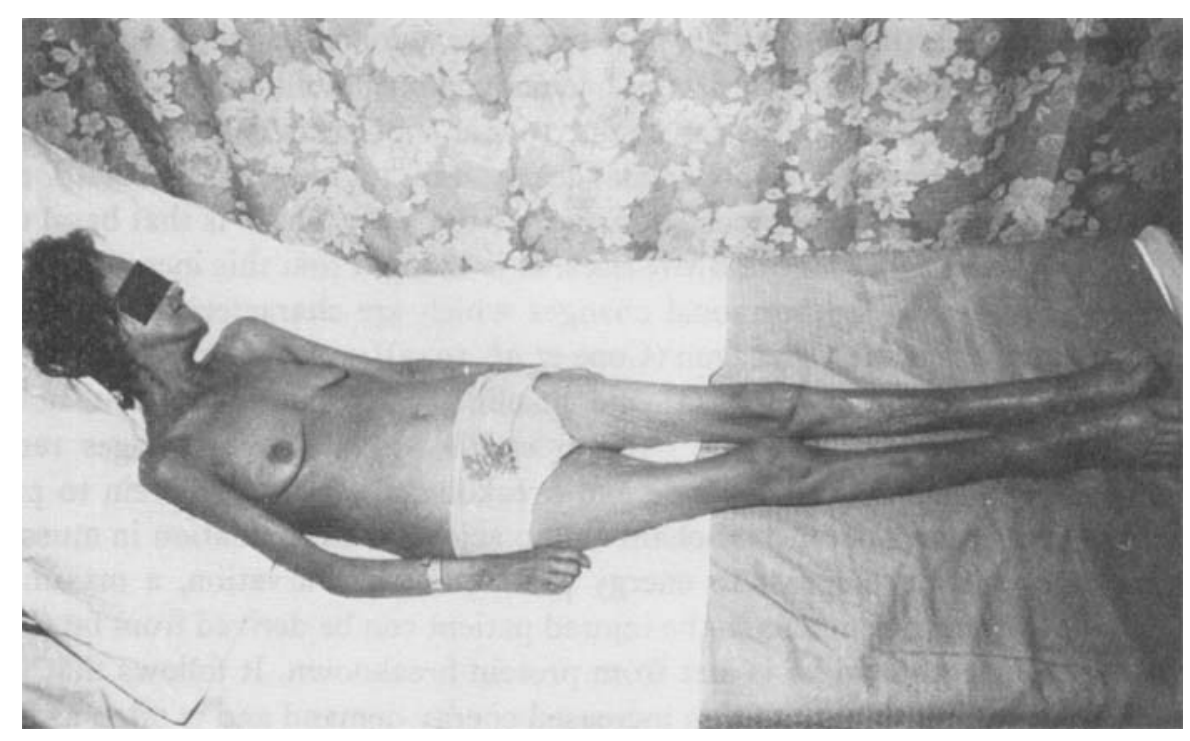

Fig. 1. Clinically-significant malnutrition in a 44-year-old patient admitted for investigation of diarrhoea and abdominal pain and found to have extensive Crohn's disease. Note the marked muscle wasting and hypoproteinaemic oedema of the ankles. Serum albumin $25 \mathrm{~g} / \mathrm{l}$.

nutritional support is requested inappropriately (e.g. malnutrition developing in the patient with terminal cancer for whom no other form of therapy is indicated).

The role of nutritional support is not just to treat established malnutrition but to prevent its onset (Silk, I 984 ). Thus, while it is clear that nutritional support is required in the grossly undernourished patient with treatable underlying disease (Fig. I), there are grounds in our opinion for providing nutritional support early on in the course of the disease if it is clear that malnutrition would otherwise develop. Nutritional support must be considered as a link in the chain of therapy, buying time for those who are treating the underlying disease process.

\section{Application of nutritional support}

If the reader adheres to the philosophy outlined previously, then there will be occasions when almost any medical condition needs inclusion. However, the following medical conditions deserve particular mention.

\section{Short-bowel syndrome}

The natural history of the short-bowel syndrome can be predicted with certainty, and patients will succumb to malnutrition unless they receive nutritional support. Specific aspects of parenteral and enteral nutrition have been reviewed (Fischer \& Freund, 1983; Betzhold \& Howard, 1984). 


\section{Inflammatory-bowel disease}

There is abundant literature on the influence that nutritional support has had on the short- as well as long-term management of inflammatory-bowel disease but it is often impossible to evaluate results because of the absence of control groups. Patients with inflammatory-bowel disease are often malnourished (Driscoll \& Rosenberg, 1978). Many of the reports have therefore been concerned with improvements achieved in nutritional status, usually in combination with bowel rest, and, at the same time, the authors have attempted to draw conclusions about patient outcome, particularly in relation to the avoidance of surgical intervention (Fischer et al. 1973). There are, however, problems inherent in the design of experiments involving patients with inflammatory-bowel disease, not only because . of the difficulties that occur in reaching a precise diagnosis, but also because of differences in duration, extent and severity of the disease, all of which may affect the response to therapy.

Five important conclusions can be drawn from the information available: (I) nutritional support, administered either by the enteral or parenteral route, in combination with medical therapy, frequently results in an improvement of the nutritional status of patients with inflammatory-bowel disease (Fischer et al. 1973; Voitk et al. 1973; Vogel et al. 1974; Reilly et al. 1976; Driscoll \& Rosenberg, I978; Dickinson et al. I980; O'Morain et al. 1984); (2) the immediate outcome of patients with colitis, due either to Crohn's disease or ulcerative colitis, is uninfluenced by parenteral nutrition (Dickinson et al. 1980) which cannot therefore be considered as primary therapy; (3) a recent study (O'Morain et al. 1984) has shown that enteral nutrition using a chemically defined elemental diet, was as effective as corticosteroids in achieving remission in patients with newly diagnosed Crohn's disease. Follow up of the patients was short, however, and the study has not yet been repeated elsewhere; (4) decisions as to whether to recommend surgery in malnourished patients with small intestinal Crohn's disease should not be made until efforts have been made to improve the nutritional status of these patients. This is because there is a strong suggestion from uncontrolled studies that surgery was unnecessary in a significant proportion of patients given nutritional support (Fischer et al. 1973; Voitk et al. 1973; Rocchio et al. 1974; Vogel et al. 1974; Reilly et al. 1976); (5) normal growth patterns in children with Crohn's disease may be restored by means of short- or long-term enteral nutrition using both elemental and polymeric diets in combination with medical therapy (Morin et al. 1980); Kirschner et al. 1981).

\section{Enterocutaneous fistulas}

The introduction of nutritional support has had a major impact on the survival of patients with enterocutaneous fistulas. Overall, mortality was in the region of 40-45\% (Edmunds et al. 1960; Chapman et al. 1964) and as high as 60\% in patients considered malnourished (Edmunds et al. 1960). Since the introduction of nutritional support, mortality has fallen to between 9 and $34 \%$ (Sheldon et al. 
1971; Dietal, 1976; Thomas \& Rossalion, 1978). The mechanism of action is far from being understood, and controversy exists as to whether nutritional support with bowel rest (i.e. parenteral nutrition) is superior to enteral nutrition using an elemental diet, which can marginally reduce ileostomy output as well as the volume of ileal fistual effluent (Hill et al. 1975, 1976). Yet again there are no controlled clinical trials to answer this point.

\section{Acute pancreatitis}

Patients with acute pancreatitis are a further group who, under certain circumstances, require nutritional support. In $70-80 \%$ of patients the abdominal pain and ileus, if present, resolve and introduction of oral feeding is possible, usually within about $5 \mathrm{~d}$ or so. These patients do not require further nutritional support.

In about one-fifth of cases (Gliedman et al. 1970), the pancreatitis persists for longer, or the patients develop haemorrhagic or post-necrotic pancreatitis, or the pancreatitis is complicated by an abscess or pseudocyst function. In these cases, some form of nutritional support is mandatory, particularly since these patients are often hypermetabolic, with $\mathrm{N}$ losses in excess of $15 \mathrm{~g} / \mathrm{d}$.

It is traditional teaching that 'resting' the gastrointestinal tract is helpful in allowing the inflammatory process to subside (Gliedman et al. 1970). Many of the patients have a localized ileus which makes nutritional support via the enteral route impractical; moreover, since a significant proportion may require surgery it is wise to institute parenteral nutrition. Few problems arise with parenteral nutrition in these patients (Warshaw et al. 1974), either with hyperglycaemia (insulin supplements may be required) or with use of a triglyceride-based energy source. Patients with severe pancreatitis definitely benefit from nutritional support.

\section{Chronic liver disease}

In the absence of encephalopathy, the nutritional status of malnourished patients can be improved by standard means and nutritional support via the enteral route instituted. Malnourished cirrhotic patients with chronic hepatic encephalopathy (PSE) are, however, faced with a nutritional dilemma. They require dietary protein to maintain $\mathrm{N}$ balance, but the ingestion of protein often precipitates encephalopathy (Phillips $e t$ al. 1952). Despite treatment with lactulose or antibiotics, many cirrhotic patients are unable to tolerate sufficient protein to prevent longstanding negative $\mathrm{N}$ balance which may contribute to further deterioration of hepatic function and general health.

In an attempt to correct the atypical plasma amino acid profile in PSE (decreased levels of BCAA, leucine isoleucine and valine and increased levels of aromatic amino acids (AAA), phenylalanine, tyrosine, free tryptophan and methionine) investigators have administered mixtures of amino acids rich in BCAA and deficient in AAA (Fischer et al. 1974; Morgan et al. 1978). With one exception (Keohane et al. 1983a), cirrhotic patients with acute encephalopathy have received nutritional support via the parenteral route. Although the initial 
uncontrolled trials (Fischer et al. 1976; Freund et al. 1982) suggested benefits of amino acid mixtures rich in BCAA and deficient in AAA, in respect of nutritional status and mental state, three subsequent controlled trials of BCAA administration (Cerra et al. 1982; Rossi-Fanelli et al. 1982; Wahren et al. 1983) using different experimental designs and different amounts and types of BCAA solution, have come to different conclusions. The pitfalls of these trials have been discussed by Horst et al. (1984) and Walser (1984). Only one trial (Cerra et al. 1982) reports a significant benefit of BCAA-enriched solutions. The other two trials failed to show a significant benefit either in terms of survival or mental state (Rossi-Fanelli et al. I982; Wahren et al. 1983). Although all three studies showed a positive effect of amino acid infusion on $\mathrm{N}$ balance, it is far from clear whether this represented a significant clinical advance.

As far as cirrhotic patients with chronic PSE are concerned, two cross-over studies (Eriksson et al. 1982; McGhee et al. I983) failed to show any beneficial effect of supplementing normal nutritional intake with either oral supplements of BCAA alone (Eriksson et al. 1982) or with oral supplements consisting of a BCAA-enriched amino acid mixture ( $\mathrm{McGhee}$ et al. 1983). In the most recent studies (Horst et al. 1984), thirty-seven patients in two groups were given increasing amounts of diets based either on dietary protein or a BCAA-enriched amino acid solution. Both groups of patients attained positive $\mathbf{N}$ balance, but encephalopathy was induced significantly less frequently in the group receiving the BCAA-enriched diet: this may be a significant advance in the nutritional management of these difficult patients.

\section{REFERENCES}

Abbott, W. E. \& Albertsen, K. (1963). Annals of the New York Academy of Science 110, 941.

Allison, S. P., Hinton, P. \& Chamberlain, M. J. (1968). Lancet ii, I I $13-1116$.

Baker, J. P., Detsky, A. S., Whitwell, J., Langer, B. \& Jeejeebhoy, K. N. (1982). Human Nutrition: Clinical Nutrition 36C, 233-24I.

Bastow, M. D., Rawlings, J. \& Allison, S. P. (1983). British Medical fournal 287, $15^{89}-1592$.

Betzhold, J. B. \& Howard, L. (1984). In Enteral and Tube Feeding, pp. 338-362 [J. L. Rombeau and M. D. Caldwell, editors]. Philadelphia: W. B. Saunders Co.

Bristian, B. R., Blackburn, G. L., Vitale, J., Cochrane, D. \& Naylor, J. (1976). Fournal of the American Medical Association 235, I 567-1 570.

Buzby, G. P., Mullen, J. L., Matthews, D., Hobbs, C. L. \& Rosato, E. F. (1980). American foumal of Surgery 139, I60-166.

Cerra, F. B., Cheung, N. K., Fischer, J. E., Kaplowitz, N., Schiff, E. R., Dienstag, J. L., Marbry, C. D., Leevy, C. M., Kiernan, T. (1982). Hepatology 2, 699, Abstr.

Chapman, R., Foran, R. \& Dunphy, J. E. (1964). American Journal of Surgery 108, 157-164.

Cope, C., Nathanson, I. T., Rourke, G. M. \& Wilson, H. (1943). Annals of Surgery I I 7, 937-948.

Daly, J. M., Vars, H. C. \& Dudrick, S. J. (1972). Surgery, Gynaecology and Obstetrics $134,15-21$.

Dickinson, R. J., Ashton, M. G., Axon, A. T. R., Smith, R. C., Yeung, C. K. \& Hall, G. L. (1980). Gastroenterology 79, $1199-1204$.

Dietal, M. (1976). Canadian Fournal of Surgery 19, 505-51 I.

Dowd, P. S. \& Heatley, R. V. (1984). Clinical Science 66, $24^{1-248 .}$

Driscoll, R. H. \& Rosenberg, I. H. (1978). Medical Clinics of North America 62, 185-201.

Edmunds, L. H., Williams, G. M. \& Welch, C. E. (1960). Annals of Surgery 152, 445-471.

Eriksson, L. S., Persson, A. \& Wahren, J. (1982). Gut 23, 801-806. 
Fischer, J. E., Foster, G. S., Abel, R. M., Abott, W. M. \& Ryan, J. A. (1973). American fournal of Surgery 125, $165-175$.

Fischer, J. E. \& Freund, H. R. (1983). In Surgical Nutrition, pp. 663-702 [J. E. Fischer, editor]. Boston: Little Brown \& Co.

Fischer, J. E., Rosen, H. M., Ebeid, A. M., James, J. H., Keane, J. M. \& Soeters, P. B. (1976). Surgery 80, 77-91.

Fischer, J. E., Yoshimura, N., Aguirre, A., James, J. H., Cummings, M. G., Abel, R. M. \& Deindoerfer, F. (1974). American fournal of Surgery 127, 40-47.

Freund, H., Dientag, J., Lehrich, J., Yoshimura, N., Bradford, R. R., Rosen, H., Atamian, S., Slemmer, E., Holroyde, J. \& Fischer, J. E. (1982). Annals of Surgery 196, 209-220.

Gassull, M. A., Cabre, E., Vilar, L., Lastine, A. \& Motserrat, A. (1984). Human Nutrition: Clinical Nutrition 38C, 419-43I.

Gliedman, M. L., Boboki, H. \& Rosen, R. G. (1970). Current Problems in Surgery, I-52.

Grande, F. (1968). American foumal of Clinical Nutrition 21, 305-314.

Hill, G. L., Mair, W. S. J., Edwards, J. P. \& Goligher, J. C. (1976). British fournal of Surgery 63, $133-136$.

Hill, G. L., Mair, W. S. J., Edwards, J. P., Morgan, D. B. \& Goligher, J. C. (1975). Gastroenterology 68, 676-682.

Horst, D., Grace, N. D., Conn, H. O., Schiff, E., Schenker, S., Viteri, A., Law, D. \& Atterbury, C. E. $(1984)$. Hepatology 4, 279-287.

Jeejeebhoy, K. N., Baker, J. P., Wolman, S. L., Wesson, D. E., Langer, B., Harrison, J. E. \& McNeill, K. E. (1982). American fournal of Clinical Nutrition 35, I I $17-1$ I 27.

Jones, B. M. J., Lees, R., Andrews, J., Frost, P. \& Silk, D. B. A. (1983). Gut 24, 78-84.

Keohane, P. P., Attrill, H., Grimble, G. K., Spiller, R. C., Frost, P. \& Silk, D. B. A. (1983a). Fournal of Parenteral and Enteral Nutrition 7, 346-350.

Keohane, P. P., Attrill, H., Love, M., Frost, P. \& Silk, D. B. A. ( $1983 b)$. Clinical Nutrition 2, I19-122.

Kinney, J. M., Duke, J. H., Long, C. L. \& Gump, F. E. (1970). Fournal of Clinical Pathology 23, Suppl. $4,65-72$.

Kirschner, B. S., Klich, J. R. \& Kalman, S. S. (1981). Gastroenterology 80, 10-15.

Klidjian, A. M., Archer, T. J., Foster, K. J. \& Karran, J. J. (I982). Fournal of Parenteral and Enteral Nutrition 6, I 19-121.

Koretz, R. L. (1984). Digestive Diseases and Sciences 29, 577-588.

Lee, H. A. (1979). Research and Clinical Forums I, $15^{-24}$.

McGhee, A., Henderson, M., Millikan, W. J., Bleier, J. C., Vogel, R., Kassoury, M. \& Rudman, A. (1983). Annals of Surgery 197, 288-293.

Meakins, J. L., Pietsch, J. B., Bubernick, O., Kelly, R., Rode, H., Gordon, J. \& Maclean, L. D. (1977). Annals of Surgery 186, 241-250.

Moore, F. D. (1959). Metabolic Care of the Surgical Patient. Philadelphia: W. B. Saunders Co.

Morgan, M. Y., Hilson, J. P. \& Sherlock, S. (1978). Gut 19, 1068-1073.

Morin, C. L., Roulet, M., Roy, C. C. \& Weber, A. (1980). Gastroenterology 79, 1205-1210.

Mullen, J. L., Buzby, G. P., Matthews, D. C., Smale, B. F. \& Rosato, E. F. (1980). Annals of Surgery 192, 604-613.

O'Keefe, S. J. D., El-Zayadi, A., Carraher, T. E., Davis, M. \& Williams, R. (1980). Lancet ii, 615-617.

O'Keefe, S. J. D., Sender, P. M. \& James, W. P. T. (1974). Lancet ii, 1035-1038.

O'Morain, C., Segal, A. W. \& Levi, A. J. (1984). British Medical Yournal 288, 1859-1862.

Pettigrew, R. A., Charlesworth, P. M., Farmilio, R. W. \& Hill, G. L. (1984). Fournal of Parenteral and Enteral Nutrition 8, $21-24$.

Phillips, G. S., Schwartz, R. \& Gabuzda, G. S. (1952). New England Fournal of Medicine 247, 239-246.

Reilly, J., Ryan, J. A., Strote, W. \& Fischer, J. E. (1976). American fournal of Surgery 131, I $92-200$.

Rocchio, M. A., Mo Cha, C. J., Haas, K. F. \& Randall, H. T. (1974). American Journal of Surgery $127,469-475$.

Rolandelli, R., Roruda, M., Settle, G., Scheindlin, B., Ben-Yishay, A. \& Rombeau, J. (1985). Journal of Parenteral and Enteral Nutrition 9, 106. 
Ross, H., Johnston, I. D. A., Welborn, J. A. \& Wright A. D. (1966). Lancet ii, 563-566.

Rossi-Fanelli, F., Riggio, O., Cangiano, C., Cascino, A., De Conciliis, D., Merli, M., Stortoni, M., Glunchi, G. \& Capocaccia, L. (1982). Digestive Disease and Sciences 27, 929-935.

Scrimshaw, N. S., Taylor, C. E. \& Gordon, J. E. (1959). American Fournal of Medical Science 237, $367-404$.

Scrimshaw, N. S., Taylor, C. E. \& Gordon, J. E. (1968). World Health Organization Monograph Series no. 57. Geneva: WHO.

Selivanor, V. \& Shelden, G. F. (1984). In Enteral and Tube Feeding, pp. 403-4I I [J. L. Rombeau and M. D. Caldwell, editors]. Philidephia: W. B. Saunders Co.

Sheldon, G. F., Gardiner, B. N., Way, L. W. \& Dunphy, J. E. (1971). Surgery, Gynaecology and Obstetrics $133,3^{8} 5^{-}-389$.

Shizgal, H. M., Spanier, A. H. \& Kurtz, R. S. (1976). American fournal of Surgery 131, 156-16r.

Silk, D. B. A. (1983). Nutritional Support in Hospital Practice. Oxford: Blackwell Scientific Publications.

Silk, D. B. A. (1984). Postgraduate Medical fournal 60, 779-790.

Spanier, A. H., Pietsch, J. B., Meakins, J. L., Maclean, L. D. \& Shizgal, H. M. (1976). Surgical Forum 27, 332.

Sutton, G. \& Karran, S. J. (1985). Current Opinion in Gastroenterology, vol r. London: Gower Academic Medical Journals.

Thomas, R. J. S. \& Rossalion, A. (1978). Australian and New Zealand fournal of Surgery 48, 535-547.

Vogel, C. M., Corwin, T. R. \& Baue, A. E. (1974). Archives of Surgery 107, 329-333.

Voitk, A. J., Echave, B., Feller, J. H., Brown, R. A. \& Gurd, F. N. (1973). Archives of Surgery 107, 329-333.

Wahren, J., Denis, J., Desurmont, P., Eriksson, L. S., Escoffier, J. M., Gauthier, A. P., Hagenfeldt, L., Michael, H., Opolon, P., Paris, J. C. \& Veyrac, M. (1983). Hepatology 3, 475-480.

Walser, M. (1984). Clinical Science 66, I-15.

Warshaw, A. L., Imbembo, A. L., Civetta, J. M. \& Dagget, W. M. (1974). American fournal of Surgery 127, 484-491.

Woolfson, A. M. J. (1979). Research and Clinical Forums 1, 35-48. 